\title{
Community Involvement and Ecotourism in Doi Inthanon National Park,Thailand
}

\author{
Meemana Jiraya1
} ${ }^{1}$ School of Landscape and Architecture, Beijing Forestry University, No. 35, Qinghua East Road, Haidian District,
Beijing, 100083, P.R. China

\begin{abstract}
Ecotourism has been identified as one of the tourism's subsector that is fastest growing globally. Ecotourism offers opportunity to the local people in learning and using the area as attractions for the tourists. It's not only sustain the conservation of the environment, but also improve the welfare of local people, especially people staying within the area. The direct involvement of local community in management of resources area will encourage them to appreciate the value of the resources and fight against any form of misuse or encroachment, as they have the sense of the belonging and responsibility to the area. Thailand is one of rich flora, fauna and cultural diversity country and becoming one of the popular ecotourism destination. According to the definition by the National Parks Act, Thailand has 154 national parks covering an area of 6.24 million hectares, includes both terrestrial and marine parks such as the highest land of Thailand "Doi Inthanon National Park". This paper highlights the involvement of local community in Doi Inthanon National Park, where there are 9,792 residents living within the national park. Currently, there are four villages has been involved directly in the ecotourism activities of the Doi Inthanon National Park. However, there are no coordination among the groups that involved in the ecotourism activities, which may lead to unsustainable and confuse among the tourist. Realizing that problem, this paper recommends that relevant authorities to coordinate and help local community by providing guidance and capacity building.
\end{abstract}

\section{Introduction}

Ecotourism is one of the important and fastest growing sectors in the tourism industry recently. Tourists will be experienced to visit undisturbed natural areas and beautiful scenery including wildlife and flora. $\mathrm{H}$. Ceballos (1983) defined the ecological tourism means to appreciate and enjoy landscape, wildlife and animal activities, as undisturbed or non-polluting natural areas of tourism resource (Zhang, 2008; James (Ed)., 2007). Since that, research and development on ecotourism has been increased. Ecotourism should have the criteria, among others be the lowest impact on natural resources in protected areas; participation of various stakeholders included government agencies, communities, tourist, tour operators etc. in planning, development, implementation and monitoring; respecting local culture and traditions; sustainable and fair income for local communities and other stakeholders, including private tourism operators; educate all stakeholders to make their contribution to soil and water conservation (Sheryl and Geoffrey,1999). Consequently, ecotourism includes natural tourism, community tourism, homestay, world heritage tours and other forms of responsible travel. While, the term ecology is often used to refer to small-scale enterprises and operations, the principle of sustainable tourism applies to all types and all forms of tourism, from mass tourism to niche markets (IUCN and Kuoni, 2012).
Thailand is one of rich flora, fauna and cultural diversity country and becoming one of the popular ecotourism destination. It is located in South East Asia, situated in the tropical area between latitudes $5^{\circ} 37 \mathrm{~N}$ to $20^{\circ} 27 \mathrm{~N}$ and longitudes $97^{\circ} 22 \mathrm{E}$ to $105^{\circ} 37 \mathrm{E}$ (Climatological Center, 2015). It covers a total land area of 513,115 sq. $\mathrm{km}^{2}$ and its bordered by Cambodia, Lao PDR, Myanmar and Malaysia (Department of lands, 2017). In the high mountain at the north part of the country and southern part consists of the precious marine resource. The climate of Thailand is under influence of monsoon winds character which can be divided into three seasons dominated by rainy season (mid-May to mid-October), winter season (mid-October to mid-February) and summer season (mid-February to mid-May). The average temperature of Thailand is about $27.9^{\circ} \mathrm{C}$. The minimum temperature about $0^{\circ} \mathrm{C}$ and the maximum temperature recorded was $41.1^{\circ} \mathrm{C}$ (Climatological Center,2016). From northern to southern of land have different geography and temperature but each area has prominent of natural resource and cultural resource that need to protect.

Consequently, the Government of Thailand legislate the Wild Animal Reservation and Protection Act (1960) and National Park Act (1961), to conserve and protect the wildlife and forest lands. According to the National Parks Act of 1961, a national park is defined as "any land or natural feature which is of interest to be

This article is published under the terms of the Creative Commons Attribution License 4.0

Author(s) retain the copyright of this article. Publication rights with Alkhaer Publications.

Published at: http://www.ijsciences.com/pub/issue/2018-04/

DOI: 10.18483/ijSci.1634; Online ISSN: 2305-3925; Print ISSN: 2410-4477 
maintained with a view to preserving that for the benefit of public education and pleasure, with the provision that such land is not owned or legally possessed by any person other than a public body". The objectives of the establishment of national parks are to conserve the natural resource and ecological system; to provide approaches for education and scientific research; and to enhance and facilitate the recreation for people (Wiwik,2012; Songsak and Komkrit, 2017). According to the definition by the National Parks Act, Thailand has 154 national parks covering an area of 6.24 million hectares (Department of National Parks, Wildlife and Plant Conservation,2017). It includes both terrestrial and marine parks such as the highest land of Thailand "Doi Inthanon National Park", the most beautiful waterfall "Erawan National Park", the most popular marine park "Hat Noppharat Thara-Mu Ko Phi Phi National Park", the biggest and most plenteous of forest and wildlife "Khao Yai National Park". Despite of being a wonderful destination for traveling, national park has become new resources of wealth for the Government of Thailand. According to the statistic from Thailand's National Park Office, the beautiful and uniqueness of national parks in Thailand has attracted more than 18 million visitors, both local and foreigner to visit national parks in Thailand as of 2017. The revenue collected only cover from the entrance fee is approximately 114 million Thai Baht or 3.55 million USD (National Park Office,2017).

However, the massive number of tourist especially without proper management and during peak season, has bring negative impacts to the natural resource, environment and local community in national park. In this regard, the National Park Office applied an appropriate management system by using the concept of local community involvement in ecotourism activities. This concept is quite useful concept to promote local communities to be involved in the management of national park, such as local people can give their suggestions and ideas to improve and solutions for any problems occurs within the national parks. The local communities' involvement gives the benefit and economic opportunity not only for them, but also to the management of national park in term of conservation purpose. This study will highlight on how local communities involve in national park ecotourism and how local communities and national park get benefit.

\section{Doi Inthanon National Park \\ 2.1 General information of Doi Inthanon National Park}

Doi Inthanon National Park was established in 1978, number sixth of Thailand's national park. Its located in Chiangmai Province, northern part of Thailand. With an area of 1,190.45 square kilometer, the National Park distributed to an elevation up to 2,565 meters from sea level. it spread over 3 district 7 sub-district which covered about 40 villages (Department of National Park, Wildlife and Plant Conservation,2012). There are 16 villages with 9,792 residents living within the national park. While, 24 villages with 12,999 residents staying nearby the border of Doi Inthanon National Park (Academic of Doi Inthanon National Park,March $16^{\text {th }}$ 2016). The climate in this area is dominated by rainy, winter and summer season. Doi Inthanon Park is one of the most important national park of Thailand because it has the most luxuriant forest cover. There occurs heavy rain, many streams originate and much waterfall. Besides, there are some special high land plant communities, about 1,274 plant species, where 37 species are newly discovered. The Doi Inthanon National Park is home to more than 385 species of bird, out of 978 species of the bird in Thailand (The $16^{\text {th }}$ Conservation Area Administration Office, 2011). The Doi Inthanon National Park is one of the most popular ecotourism area in Thailand because of the unique and attractive among others, summit of a mountain, where located the highest point of Thailand, Kew Mea Pan natural trail, Pha dok siao natural and cultural trail, King's 9 and Queen Pagoda, "Mae Ya waterfall", the top ten most beautiful waterfalls in Asia (www.world-of-waterfalls.com), and local tribe villages. Figure 2 show the map of Doi Inthanon National Park. 


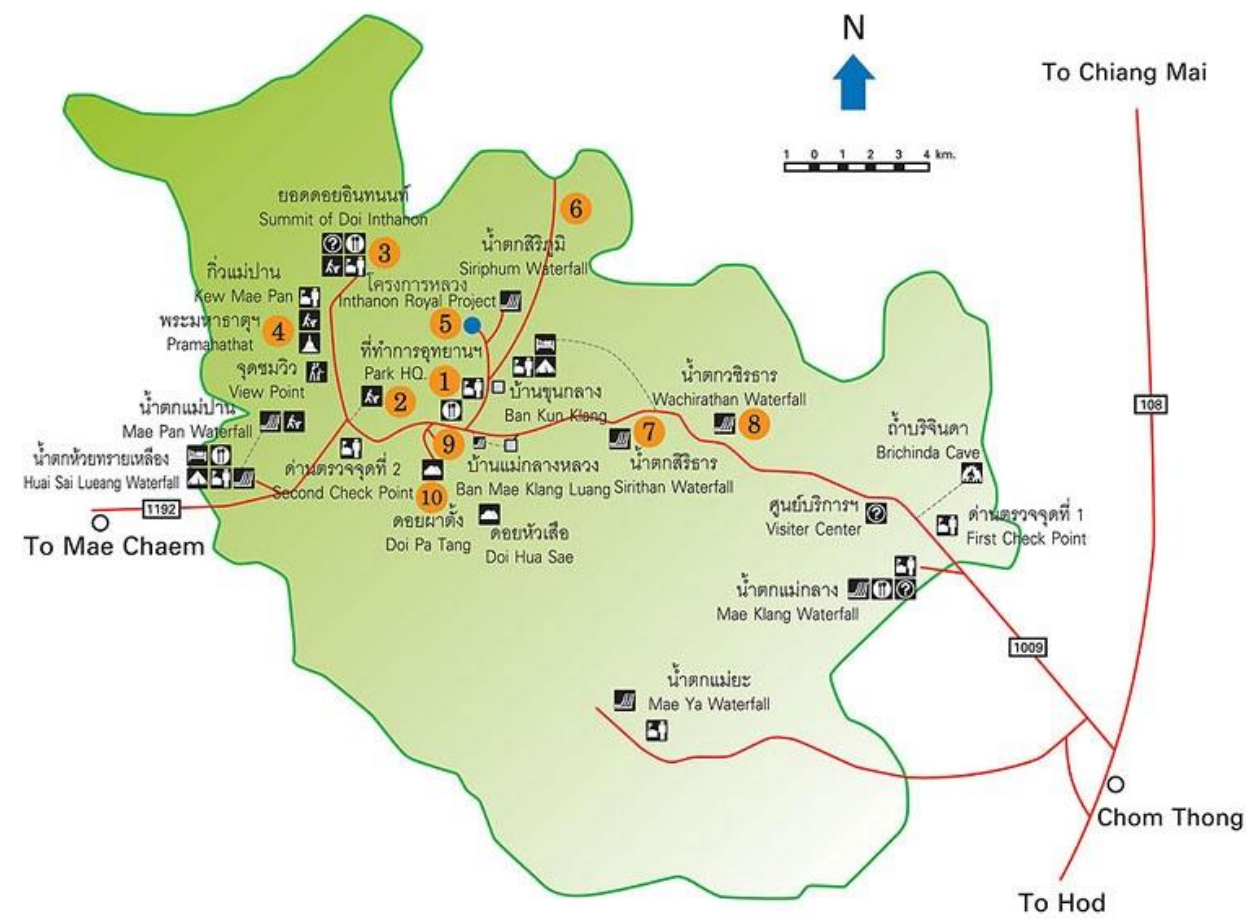

Source: Department of National Parks, Wildlife and Plant Conservation, 2017

\section{Management of Doi Inthanon National Park 3.1National Park Management}

The concept of a national park was initiated after the World War II. In 1943, Phu Kradueng National Park was established for the first national forest park in Thailand. However, the situation of the World War II made this effect difficult to achieve. In September 1959, the Board of Directors national parks was appointed by the cabinet to develop project and manage the protection of natural resources by order of Field marshal Sirit Thanarat, the Prime Minister of Thailand (1959-1963) (The National Parks Conservation Club, 1951). They begin to survey for the establishment of national park with the assistance from Dr. George D. Ruhle, the natural specialist of United Stated of America National Park Service and International Union for Conservation of Nature (IUCN) (George, 1964). Khao Yai National Park was the first national park of Thailand in 1962 (National Park, Wildlife and Plant Conservation Department,2010) which is under the jurisdiction of Royal Forest Department (George, 1964).

National park is state own property which is control by the Ministry of Natural Resources and Environment. It consists of several technical department namely, Department of National Parks, Wildlife and Plant Conservation; Department of Marine and Coastal Resources; Department of Mineral Resources; Department of Water Resources; Department of Groundwater Resources; Department of Environmental
Quality Promotion; Office of Natural Resources and Environmental Policy and Planning; and Royal Forest Department.

In 2 October 2002, the Department of National Parks, Wildlife and Plant Conservation was separated from Royal Forest Department focusing more on conservation, reserves, coverage, refreshed, manage and cultivating for forest, wildlife and plant. The sustainable resource management has been implemented by preventing and monitor the activities and awaken consciousness for a tenacious sense of community and participate in conservation and protection of local resources. It is important to maintain the balance of the ecosystem and the environment, including biological diversity in the national park, the wildlife sanctuary, the law and regulations related to illegal hunting area and other task as required by the law (National Park, Wildlife and Plant Conservation Department, 2015). The main function of national park office is planning and developing a management plan for the national park. While, the Conservation Area Administration (1-16) functioning for the implementation and monitoring process, which also carried out by the park office under the approval of the ministry. Every national park areas have their own office which is responsible for all the management and administration activities within the park. Figure 1 show the organizational structure of national park areas in Thailand. 
Figure 1 The Organizational Structure of National Park Areas

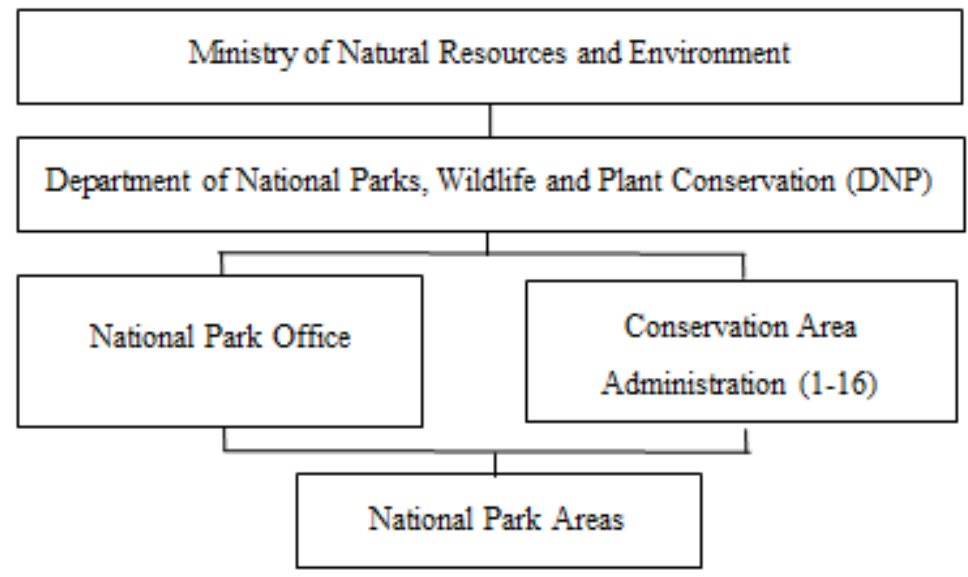

Source: National Park Office,2017

\subsection{Policy Implementation}

1) Government policy

From the $11^{\text {th }}$ government of field marshal Sarit Thanarat (1959-1963), the government has increased the policy to emphasize the importance of forest and wildlife in the country. The national park officials have impact to every government organization, where they need to obey the direction and follow each government policy (Royal Thai Government, 2017). The government of national council for peace and order policy in 2017-2021 promote the protected resource base and make a balance between conservation and sustainable use. The policy among others indicate on the protection and restoration of the conservation area, make clear government land line by technology information system; improve the law, reforestation in buffer areas; promote the ecosystem economics valuation approach and monetize the conservation; and fix the invasion of state land by the Royal initiative so that the people can live within the forest by $5 \mathrm{~S}$ policy namely Stability, Strengthening, Show transparency, Strategy, and Sustainable management (Songtham et al, 2017)

The Twelfth's National Economic and Social Development Plan (2017-2021) focus on support green growth which is friendly to both the environment and the quality of life, by means targeted of forty percent of the country is forest area, classified into forest for conservation ( 25 percent), and commercial forest (15 percent), the mangrove forest area is enlarged to 2528 sq. $\mathrm{km}^{2}$ and watershed restoration areas also grow substantially. To achieve the target, few development guidelines and strategies has been initiated, namely conserve and restore forest resources to create a balance with nature; conserve and use biodiversity sustainability; develop land management systems and resolve public land encroachment; protect marine resources and prevent coastal erosion; and plan and manage mineral resources to optimize their utilization whilst minimizing the impacts on the environment and human beings (The Twelfth National Economic And
Social Development Plan(2017-2021)).

\section{2) Laws}

The main law for the management of the national parks in Thailand is The National Park Act (1961), which identify national park as "When it is deemed appropriate to determine any area of land, the natural features of which are of interest and to be maintained with a view to preserving it for the benefit of public education and pleasure, the government shall have the power to do so by a Royal Decree, a map showing the boundary lines of the determined area shall be annexed to such Royal Decree and mark sufficiently for enabling the public to know the boundary of the national park"(Section 6 and 8, National Park Act 1961). This act also requires a "National Park Committee" for controlling with two years appointed by duty of determination of land to be reserved as national park and extension or cancellation of the national park, protection and maintenance of the national park and matters consulted by the Minister (Section 9-10 and 15, National Park Act 1961).

In addition, the National Park Act 1961 also listed the illegal action within national park to protect its resources and ecosystem such as hold or possess land, or clear or burn the forest, collect, take out, or do by any means whatsoever things endangering or deteriorating woody plant, gum, yang, wood-oil, turpentine, mineral or other natural resources. The Act also mention that causing trouble or nuisance to any person or wildlife and affect local people and community and forest (Section16, National Park Act (1961), will be charged under section 16 , which will be punished from five hundred baht with imprisonment of five years (Section 24-27, National Park Act 1961). Section 30 mention that any concession or license for working timber or collecting forest product can remaining period of such concession, prospecting license, mining concession or license. That was amended in 1989 which the concessionaire shall be terminated if the concession area is a national park 
(National Park Act 1961, amendment 1989).

Despite of the National Park Act 1961, there are also associated law and regulation which contribute indirectly to the of conservation and protection of national park areas in Thailand, such as are Ivory Act (2015), Government Administration Act (No. 5) (2002), Wildlife Conservation and Protection Act (1992) (amendment 2003,2014), National Forest Act (1941). The regulation related with forest protection and wildlife conservation such as National Forest Act (1941, amendment 1989), section 68 mention that any concession in forest area shall be terminated if the concession area is a national park or wildlife sanctuary area. There are fifteen species listed as wildlife reserve, interdict hunting or possession in Wildlife Conservation and Protection Act (1992) are Pseudochelidon sirintarae, Rhinoceros sondaicus, Didermocerus sumatraensis, Bos sauveli, Bubalus bubalis, Cervus eldi, Cervus schomburgki, Capricornis sumatraensis, Naemorhedus griseus, Pitta gurneyi, Grus antigone, Pardofelis marmorata, Tapirus indicus, Muntiacus feai, Dugong dugon.. Besides, there are also
Ivory Act (2015), where its stated that trading (import and export) of ivory are forbidden. This act is a local act which function to implement the decision of Convention on International Trade in Endangered Species of Wild Fauna and Flora (CITES).

\subsection{Tourist figure}

Doi Inthanon National Park received the highest number of tourist visit in northern part of Thailand national park. Figure 3 show the number of tourist visited Doi Inthanon National Park from 2013 to 2017. From the figure, the statistic show that the number of visitors has increased. However, the number of visitors is decrease in 2017 due to the King Bhumibol Adulyadej death, where the local people grief and decrease their visit. Nevertheless, Doi Inthanon national park still being the sixth highest visitors for the national park of the country with 797,435 tourists including 125,046 foreigners and 672,389 local tourists. From the number of visitors, the national park can get revenue about 72.64 million Thai baht or 2.25 million USD (National park office, 2017).

Figure 3 Tourist Statistics of Doi Inthanon National Park

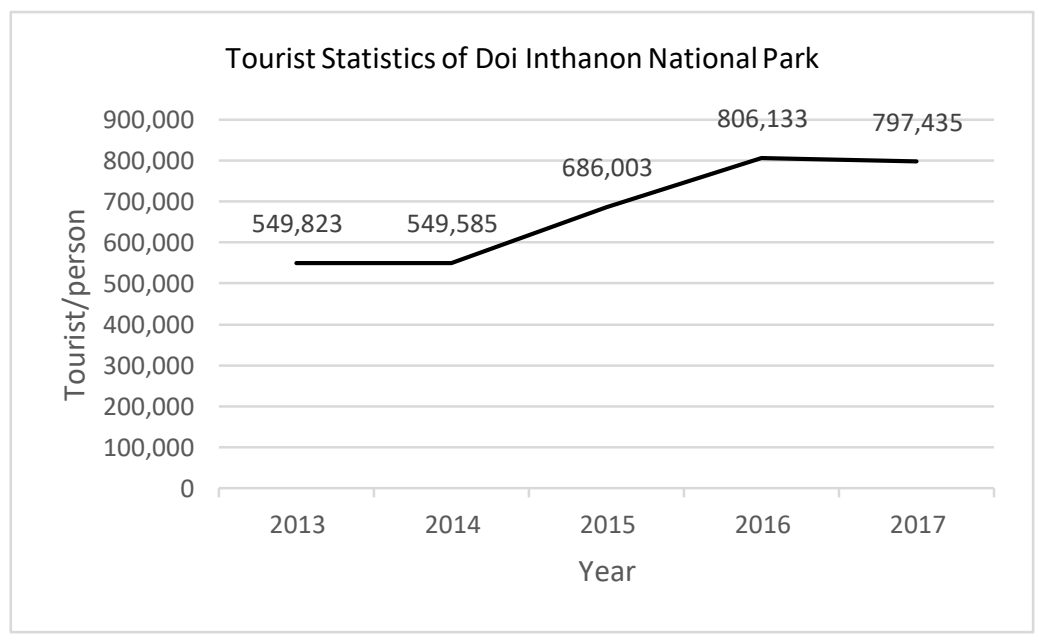

Source: National Park Office, 2017

\section{Involvement of local community in Doi Inthanon National Park}

Doi Inthanon National Park surrounded by Chom Thong district,Mea Chem district and Mea Wang district. Currently, there are four villages has been involved directly in the ecotourism activities of the national park, namely "Mae Klang Luang Village", "Khun Klang Village", "Pha Mon Village", and "Nong Lom Village". 
Figure 4 The villages involved in the ecotourism activities at Doi Inthanon National Park

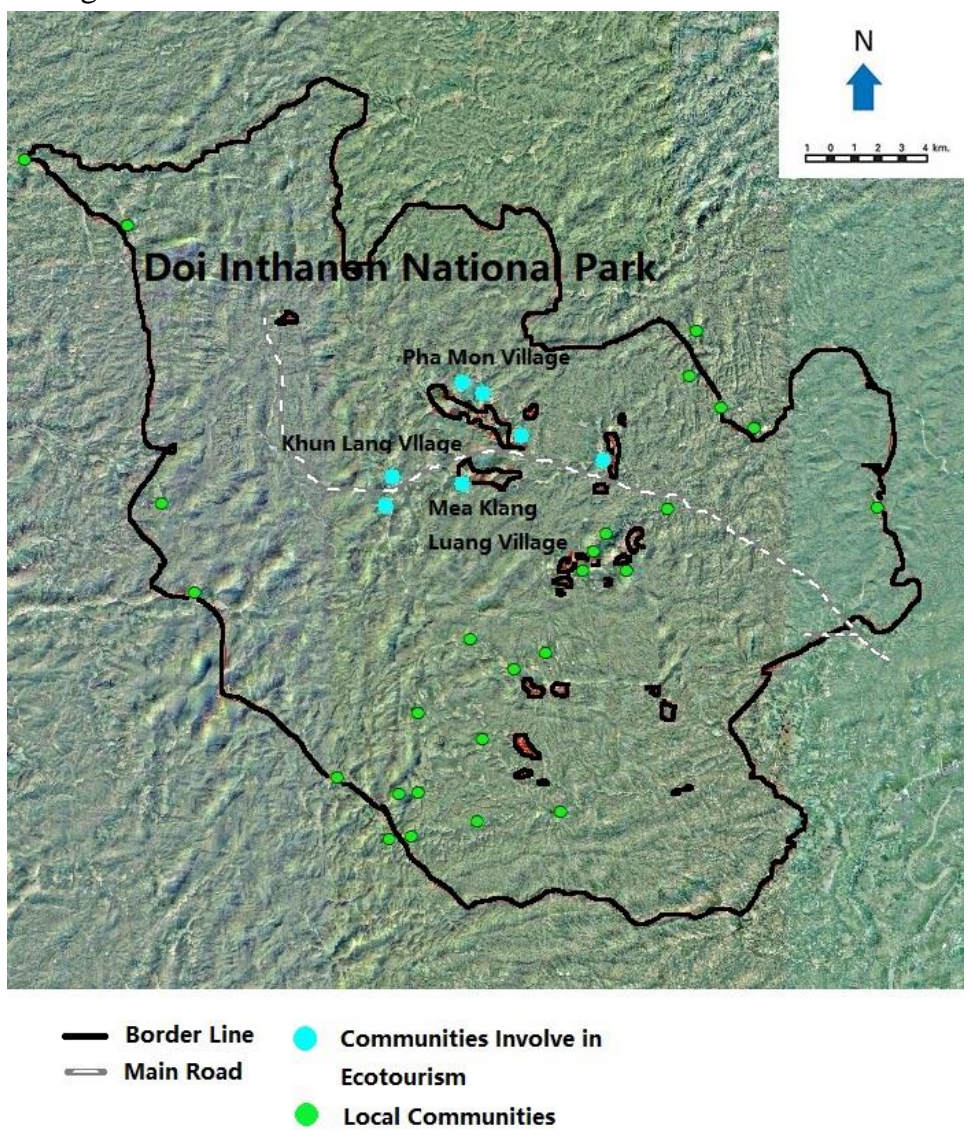

Source: Doi Inthanon National park, 2017

\subsection{Local Communities General Information}

Khun Klang Village is Hmong tribe or Meo tribe, they are independence people group came from China in 1857 to find new homeland. Some family reside in Chiangrai Province and others move in to Doi Inthanon mountain (Royal Project Foundation,2017). Presently, there are around 3,487 Mong peoples live within the Doi Inthanon National Park and 350 households or 2,031 peoples live in Khun Klang Village.

While, the people live in Mae Klang Luang Village, Pha Mon Village and Nong Lom Village originally from Karen tribe. In 1885 , the first Karen families arrived to the park area from Meahongson Province and the population recorded as 11,230 people in 2015 . Karen have simple lifestyle, where they use elephant for transportation and guardian. They have specific color dress for each sex and also it varies with the age. Men wear traditional red handwoven shirt while girls wearing white handwoven dress. In this society, married woman wears black handwoven shirt and beaded necklace (Community Development Project,2015). The population of Mae Klang Luang Village is 733 peoples with 189 households, while the population of Pha Mon Village and Nong Lom Village is about 1,032 peoples with 257 households.

Majority of the communities are farmers and they produce the agriculturist product such as rice, winter flowers, winter vegetables and winter fruits. The products were purchased by royal project foundation who is the hub of Thailand tribe agriculturist and organic vegetable market. The drought in 1997 and the catastrophe make people starve and economic of the local community's downturn. The local communities involved in the management of national park for the first time when they establish. Watershed Network Group, which is an organization aiming at conservation and protection of the river basin area within the national park. They need the support and assistance from the government especially on training and knowledge about the community-based ecotourism in order to improve the livelihood and income of the local communities. (source: interview with Mr. Rung Hirunwong, Head of Doi Inthanon National Park, 2017). Table 4 show the local community involvement in ecotourism activities at Doi Inthanon National Park.

\subsection{Local Communities Involve in Doi Inthanon National Park Ecotourism \\ 5.2.1 Local Communities Involve in Ecotourism Development Status}

Doi Inthanon National Park is one of the popular destination for travelling and always being promoted as one of a must visited place for national park categories in Thailand. Since the establishment of the national 
park, there were tourists, both local and foreigner including the film productions visited the national park. However, local communities did not get any direct benefit and yet they get impact directly from tourist behavior. In order to solve this problem and maintain the conservation status in Doi Inthanon National Park, the National Park Office promote local communities to be involved in ecotourism activities. Table 3 shows the summary of local communities' involvement in ecotourism activities at Doi Inthanon National Park.

Table 3 Local Community Involvement in Ecotourism Activities at Doi Inthanon National Park

\begin{tabular}{|c|c|c|c|}
\hline & $\begin{array}{c}\text { Mae Klang Luang } \\
\text { Village }\end{array}$ & $\begin{array}{c}\text { Pha Mon Village and } \\
\text { Nong Lom Village }\end{array}$ & Khun Klang Village \\
\hline Begin & 1999 & 2004-2005 & 1999 \\
\hline Service & $\begin{array}{c}\text { Accommodation and } \\
\text { activity }\end{array}$ & $\begin{array}{c}\text { Accommodation and } \\
\text { activity }\end{array}$ & Natural trail \\
\hline Supported & $\begin{array}{l}\text { The Thailand Research } \\
\text { Fund(Government) }\end{array}$ & $\begin{array}{l}\text { The Thailand Research } \\
\text { Fund(Government) }\end{array}$ & $\begin{array}{c}\text { Thai Rak Pa } \\
\text { Organization (NGO) }\end{array}$ \\
\hline Planning & Do research by researcher & $\begin{array}{c}\text { Do research by local } \\
\text { village }\end{array}$ & $\begin{array}{c}\text { Do research by } \\
\text { National park and } \\
\text { NGO }\end{array}$ \\
\hline $\begin{array}{c}\text { Market } \\
\text { Connection }\end{array}$ & Anonymous & A travel agency & National park \\
\hline Succession & $\begin{array}{c}\text { Depend on personal } \\
\text { attentiveness. }\end{array}$ & $\begin{array}{l}\text { Training new youth to do } \\
\text { research about community } \\
\text { ecotourism and marketing } \\
\text { with the methodically } \\
\text { (2014-2015) }\end{array}$ & $\begin{array}{c}\text { Depend on personal } \\
\text { attentiveness. }\end{array}$ \\
\hline
\end{tabular}

\subsubsection{Local Communities Involve in Ecotourism Activities}

There is natural trail in Mae Klang Luang Village, where there is a natural trail popular from a movie "The Memory". The tourists visit here and pass the village without any direct benefit but they face the problem of waste. Later, the villagers established Mae Klang Luang village tourist information center and tourist accommodation group in 1999. There are 80 members joined the program, where they manage by themselves and corporate with the national park office for their community-based activities as well as implementation of laws and regulations. The homestay group involve 11 family and they use the same tourist accommodation group management system. For the private tourist accommodation, they are 4 room allowed for each family and need to be approved by community and national park office. Besides, there is local guide group for "Pha Dok Siao trail", where it has beautiful forest and culture trail for about 2.5 kilometers in distance.Besides, there are also a group of women who make a handcraft such as weave traditional cloth and scarf. There are also 5 coffee shops in the village (source: interview with Village headman and Head of Mae Klang Luang Community Visitor Center).

Pha Mon Village and Nong Lom Village have the same management system from Thailand Research Fund to support village's leaders to do research under the project of "Sustainable Ecotourism and Cultural by Pha Mon Village, Doi Inthanon National Park, Chom Thong District, Chiangmai Province, Thailand". They learn about community-based ecotourism, the potential, knowledge, strength and how to develop and manage it. Later, they establish community-based ecotourism and villagers need to register each activity the want to involve in and this project only applicable for not accept for Pha Mon Village and Nong Lom Village They also corporate with the travel agencies for marketing and promotion purposes. The tourist will get package tour include accommodation, local food, travel natural trail, ride bicycle around village, local handcraft product. While, the member of each group will get job follow the sequence number. Nowadays, Pha Mon Village have two tourist houses and one tourist house in Nong Lom Village, so they can limit the number of tourist. Therefore, ecotourism in those village help the villagers to get extra income for temporary host, without change their daily and traditional life. For the sustainable community ecotourism, the villagers have training their new generation to gain knowledge and do research about community ecotourism and marketing in 2014-2015. (source: interview with Village headman and Head of community ecotourism group) 
Kew Mae Pan natural trail, with a distance of 3kilometres, was developed by Thai Rak Pa Organization, a non-governmental organization, with distance 3 kilometers. It is ecotourism activity for Khun Klang Village. The local people works as a tour guide and involve in activities related with the protection and conservation of forest. The member of group will get training by National Park Officer (source: interview with Village headman). Table 4 show the ecotourism activities offered by local communities in Doi Inthanon National Park.

Table 4 Ecotourism Activities Offered by Local Communities

\begin{tabular}{llll}
\hline & \multicolumn{1}{c}{$\begin{array}{c}\text { Mae Klang Luang } \\
\text { Village }\end{array}$} & \multicolumn{1}{c}{$\begin{array}{c}\text { Pha Mon Village and } \\
\text { Nong Lom Village }\end{array}$} & \multicolumn{1}{c}{ Khun Klang Village } \\
\hline \multirow{2}{*}{ Ecotourism } & 1.Tourist accommodation & 1.Tourist accommodation & 1.Local guide group \\
group and private business & group & 2.Tourist \\
& 2.Home stay group & 2.Local guide group & accommodation \\
& 3.Local guide group & 3.Local herbs group & (private business) \\
& 4.Birdwatching group & 4.Handcraft(weave) group & 3.Local agricultural \\
& 5.Handcraft(weave) group & 5.Handcraft(interlace) & products (private \\
& 6.Coffee (private business) & group & business) \\
7.Transportation (private & 6.Transportation group & 4.Transportation \\
business) & 7.Bicycle group & (private business) \\
\hline
\end{tabular}

\subsubsection{Local Communities Involve in Ecotourism Management}

Mea Klang Luang and Khun Klang village have the same management system of ecotourism group. In each group and each village, group member will choose leader and committee's group for assign duty. The committee is responsible for the management and planning of ecotourism activities, discussions with the group members, cooperation and coordination with the third parties including National Park Office, local government, NGOs, travel agency and tourists. The group manage by themselves and will cooperate when there are conservation activities.

In case of Pha Mon Village, they started from the discussions with village members, choose village members to do community base ecotourism development research and to be community in ecotourism committee. Then, they will setup ecotourism group and select leader and committee for management ecotourism in village. The committee also responsible for the management and planning of ecotourism activities, marketing, cooperation and coordination with the third parties, and discussions with village ecotourism group member. Besides, in each group activities also have a small committee group to manage duties by group. Consequently, the ecotourism management in Pha mon village are more comprehensive and all groups are interlinkage to each other. The concept achieves the objective to support village members in economic, without giving any impacts to their daily and traditional life and culture.

\subsubsection{The Benefit from Local Communities Involvement in Ecotourism}

It was 19 years since the involvement of the local communities in ecotourism activities in Doi Inthanon National Park. Overall, the local community's socio economic and livelihood was improved, especially when the low season of agriculture activities. The national park office of Doi Inthanon also hire local peoples to work with the authorities since the local people know more about the area and culture of the national park.

This opportunity also provides work and stable income to the local people, so that they do not have to migrate to another province and can work in their hometown. In addition, young generation come back to their village for working and be willing to conserve their culture, because they realized that they can generate income from the beautiful view of their village and unique culture. They also willing to learn more about their culture from the old generation, so that they can conserve the uniqueness of their ethnic and its culture. Moreover, the revenue from each ecotourism activities group will be contributed to a maximum of $10 \%$ for community benefit, education for student scholarship and school activities, social health, community activities and village development, environment and forest fire, forest patrol and reforestation. Simultaneously, their awareness on conservation and protection of the forest and wildlife also increased, whereby they created the slogan of "change hunters to be conservators".

\subsubsection{Local Communities Involve in Ecological Conservation}

The local communities also involve in conservation and patrolling activities such as restoration and rehabilitation of degraded areas, establish the fish protection areas for ecotourism purpose, decrease the 
use of chemicals in their agricultural activities. Furthermore, protection from firebreaks during summer season, they will setup the firebreak lines before summer season and patrolling in every year. This can be one of the involvement indicator, because the number of fire more less, as well as the local communities more attentive to protect national park resource.

One of the special concept, where the local communities connect their religion and faith with the conservation of natural resources. Majority of the local communities are Buddhist. In Buddhism, the peoples believe that human need to be lived harmony with nature and do something which can be harm the nature is forbidden.Every year, they will do the curse ceremony to prevent the people destroy the natural resources. The local government, national park officer, NGO, village leader, ecotourism group leader and village member will join the ceremony which will be led by religious leaders of the village and famous religious leaders from outside. The concept of connecting religion with nature conservation and protection can make people conscience and fear to against and destroy the natural resources.

\subsection{Recommendation towards Improvement of Local Communities Involvement}

Ecotourism sector in Doi Inthanon National Park was development for over the past three decades. It has been more than ten years, where the government encourage local communities to be involved in ecotourism management. However, there are still gaps and limitation which can be improved in order to make the management more efficient. Among others, the relationship between local communities themselves, especially ecotourism group is still lack and not connecting with each other. In some group activities, there are still lack of management, where they do not have any specific rules, or if have there still lack in the implementation, which always lead to a problem for group management. Moreover, there was no monitoring or controlling system for private business which also give impact to the operation in village's ecotourism. Thus, it is suggested that the relevant authorities such as local government, Ministry of Tourism as well as National Park Office to help the local communities and coordinate their involvement in order to make sure the local community can optimize the benefit they gain from their involvement, particularly for their livelihood. Besides, the relevant authorities also should help the local communities by providing guidance and capacity building for them to operate their activities which can support the ecotourism sector in Doi Inthanon National Park.

\section{Conclusion}

The local community's involvement in the management of national park, particularly in case of Doi Inthanon National Park are significant for the government, national park authorities as well as local communities themselves. Thus, there are still improvement need to be done to improve the system and management for the involvement of local communities in ecotourism activities, in order to sustain the socioeconomic benefit to the peoples as well as to maintain the conservation and protection of the Doi Inthanon National Park.

\section{References}

1. Academic of Doi Inthanon National Park. (2016). Population Inside and Border Doi Inthanon National Park.Inthanon National Park,March $16^{\text {th }} 2016$.

2. Agbor Elvis Ekwale. (2014). An Assessment of Local Community Involvement in Community Based Ecotourism Planning and Development: The Case of Takamanda National Park. South West Region, Cameroon.Eastern Mediterranean University.

3. Artit Chokwiriyawanit,Panya Mangeb,Tippawan Limanggoon. (2013). Participatory Community-Based Tourism Managementof Luangprot-Thanlium Community,Ladkrabang District,Bangkok.King Mongkut's Agricultural Journal.31:2 (47-57)

4. Chen Bang Jie. (2016). The Study on Community Participation Model of Ecotourism in Community Conservation Area, Yun Nan University.

5. Climatological Center. (2016). Annual Weather Summary over Thailand in 2015. Meteorological Development Bureau,10 February 2016.

6. Climatological Center, Meteorological Development Bureau Meteorological Department, Thailand. (2015). The Climate of Thailand Meteorological Development Bureau.

7. Cohen, J, \& N. Uphoff. (1980). Participation's place in rural development: Seeking clarity through specificity. World Dev. $8: 213-235$.

8. Community Development Project.(2015).Information of Ban Phamon Ban Luang Sub-district Chomthong District Chiangmai.PTT Group.

9. Cullinane Thomas, C., and L. Koontz. (2017). The 2016 National Park Visitor Spending Effects: Economic Contributions to Local Communities, States, and the Nation. Natural Resource Report NPS/NRSS/EQD/NRR-2017/1421. National Park Service, Fort Collins, Colorado.

10. Department of National Parks, Wildlife and Plant Conservation. (2012). 50 Years Thailand's National Park.Department of National Parks, Wildlife and Plant Conservation,Bangkok.

11. Department of National Parks, Wildlife and Plant Conservation. (2017). National Park Area 2016.

12. Department of National Parks, Wildlife and Plant Conservation. http://park.dnp.go.th/visitor/nationparkshow.php?PTA_CODE= 1006 [Accessed January $8^{\text {th }} 2018$ ]

13. Department of

(2017).http://nam.dol.go.th/Pages/internet.aspx[Accessed February $8^{\text {th }} 2018$ )

14. George C.Ruhle,Ph.D.(1964). Advisory Report on a National Park System for Thailand 1959-1960. Special Publication No.17 American Committee for International Wildlife Protection. New York.

15. IUCN and Kuoni. (2012). Integrating Business Skills into Ecotourism Operations. Switzerland, IU CN and Kuoni.

16. Jamal, T. \& Stronza, A. (2009). Collaboration Theory and Tourism Practice in Protected Areas: Stakeholders, Structuring and Sustainability. Journal of Sustainable Tourism, 17:169-189.

17. James Higham (Ed). (2007). Critical Issues in Ecotourism:Understanding a Complex Tourism Phenomenon.Butterworth-Heinemann,America.

18. National Park Act 1961, amendment 1989. (1989). Office of the Council of State.January $14^{\text {th }} 1989$.

19. National Park Act 1961. (1961). Office of the Council of State. 
September $22^{\text {nd }} 1961$.

20. National park office. (2017). The National Park's revenue of visitors and vehicles 2017. http://portal.dnp.go.th/Content/nationalpark?contentId=3719 [Accessed January $8^{\text {th }}$ 2018]

21. National Park, Wildlife and Plant Conservation Department. (2010). Kao Yai National Park Planning Model Report.

22. National Park Office. (2017) http://portal.dnp.go.th/DNP/FileSystem/download?uuid=8ce5f3 db-b2d5-4296-adcd-0c1a84fdcca8.pdf [Accessed October $9^{\text {th }}$ 2017]

23. Office of the Forest Land Management. (2016). Forest Area in 1973-2015.Royal Forest Department.

24. Royal Project Foundation http://www.thairoyalprojecttour.com/?p=1438 January $8^{\text {th }} 2018$

25. Royal-Inthanon. (no year).King's Multifarious Duties in Inthanon. Royal Project Foundation.

26. Sheryl Ross and Geoffrey Wall. (1999). Ecotourism:towards congruence between theory and practice. Tourism Management.

27. Songtham Suksawang et al. (2017). National Park Integrated Planning 2018-2022.Sector of National Park Research and Development.Department of National Park, Wildlife and Plant Conservation.

28. Songsak Sulsawang and Komkrit Satebubpha .(2017).
Operation of Protected Area Committee Participation in Conservation Areas.Catalyzing Sustainability of Thailand's Protected Area System(CATSPA). Department of National Parks, Wildlife and Plant Conservation.

29. The National Parks Conservation Club. (1951). Field marshal Sirit Thanarat Hitory of National Park and Wildlife Act1908-1951. National Park 55 Thailand.http://www.nationalparkthailand.com/index.php?lay=s how \&ac=article \&Id=539934875. [Accessed August 21,2016]

30. The Regulation of National Park, Wildlife and Plant Conservation Department. (2008). The Rules of National Park's Revenue Management.

31. The $16^{\text {th }}$ Conservation Area Administration Office. (2011). Doi Inthanon National Park Information.Department of National Park, Wildlife and Plant Conservation.

32. United Nation Association of Greater Boston. (no year). Thailand: Information from the CIA World Factbook https://msmunatunagb.wikispaces.com/file/view/Thailand.pdf

33. Wiwik Mahdayani. (2012). Ecotourism in the NationaI Parks of Thailand. DESMA Center, Indonesia.

34. Yu Peng Fei. (2009). The Demonstration Research on Ecotourism Based on Community Participation :Case Study on Shuimogou Community, Xinjiang Normal University.

35. Zhang yu jie. (2008). Analyzes on our country eco-tourism.northeastern university. 